\title{
РАБОТЫ ПОСЛЕДНИХ ЛЕТ НА ПАМЯТНИКАХ РАННИХ КОЧЕВНИКОВ ИЛЕКСКОГО МИКРОРАЙОНА (предварительные итоги)
}

\author{
(C) 2019 г. А.А. Бисембаев, А.И. Хаванский, Г.А. Ахатов, \\ М.Н. Дуйсенгали, А.М. Мамедов, Н.Т. Бидагулов, А.Б. Уразова, \\ В.А. Амелин, Н.М. Баиров
}

В статье отражены результаты исследований памятников ранних кочевников Илекского локального микрорайона Приаральско-Мугалжарского региона, полученные за последние несколько лет. Работы ведутся с 2015 г. Планомерные исследования сосредоточены в окрестностях села Родниковка (Мартукский р-н, Актюбинская обл.). Данная группа памятников приурочена к бассейну р. Илек и выделена в соответствующий микрорайон. Раскопками исследовались курганы на могильниках Бисоба, Шпаки II, Кураша I и Кайынбулак II. Новые данные, а также материалы, полученные в 1960-1980-х гг., позволяют говорить о значительной концентрации населения и элитарном характере кочевых групп, проживавших здесь в середине I тыс. до н.э. Значительные размеры объектов, обнаруженные бронзовые котлы, литые предметы конской сбруи, каменные жертвенники, предметы вооружения и многое другое, являются яркими признаками доминирующей группы в регионе.

Ключевые слова: археология, Илек, Бисоба, Шпаки, Кураша, ранние кочевники, сарматы, погребальный обряд

Исследования, проводимые с 2015 г. в Западном Казахстане, связаны с его природно-географическим районированием. Восточная часть этой территории находится в пределах Актюбинской области и относится к Приаральско-Мугалжарскому географическому региону. Западный Казахстан характеризует значительное разнообразие, последовательная смена крупных природных зон - от лесостепи в долине Урала до пустынь Северного Приаралья. Поэтому изучение памятников различных эпох и наиболее многочисленных - раннекочевнических - весьма перспективно, исходя именно из природногеографического районирования.
Природно-географические характеристики рассматриваемого региона оказывали важнейшее влияние на особенности и количественный состав памятников ранних кочевников. Оформление природноклиматических характеристик в тех чертах, что мы наблюдаем сегодня, отразилось на хозяйственных занятиях населения, проявилось в формировании пастбищно-кочевой системы - основы экономики номадных обществ [Акишев, 1972, с. 31]. У кочевых образований на левом берегу Урала в VI-IV вв. до н.э. сложился крупный племенной союз, консолидирующая группа (элита) которого избрала местом своего обитания сред- 
нее течение магистральной артерии, по обоим берегам наиболее крупного левобережного притока. Иллюстрацией этому служат яркие комплексы Кырык Оба, Лебедевка, Покровка и т.д. Особенность данной ситуации была подмечена К.Ф. Смирновым еще в период первых исследований в бассейне Илека, вынесшим географическую локализацию в название монографии [Смирнов, 1975].

Система гидросети, направленность и сосредоточие водных артерий являются важнейшими факторами влияния на кочевую экономику, характер проживания населения, его концентрацию и т.д. Западный Казахстан расположен в европейской и азиатской частях Евразии с соотношением по площади порядка 7:3. Граница между этими частями света в пределах Казахстана проводится по Мугалжарам, Эмбе и по геологическим разломам в северной части акватории Каспийского моря - озера. Природные различия между западной и восточной частями региона, к востоку от р. Эмба, очевидны: ландшафт резко приобретает азиатский характер (главным образом из-за смены состава биот и биомов). Регион имеет наибольшее протяжение с севера на юг - около 900 км, с запада на восток около 1200 км и занимает площадь в 729,2 тыс. кв.км.

Факторы природно-географического характера представляют собой исторический фон, обусловивший, в конечном итоге, расположение, количественный состав и специфику памятников кочевого населения в раннем железном веке. Важность и необходимость анализа региональных особенностей, возникающие из территориального фактора - значительных размеров и, соответственно, различных природно-географических условий Западного Казахстана, для раннего железного века приобретает особую актуальность [Бисембаев, 2009, с. 217]. В этой связи появляется возможность внутрирегионального сравнения памятников по локальным микрорайонам, применение как внутренней корреляции, по признакам погребального обряда и основным элементам материальной культуры, так и внешней, связанной с сравнением с памятниками крупных соседних регионов - Южного Приуралья, Нижнего Поволжья, Южного Приаралья, Центрального и Северного Казахстана. Локализация и картографирование выявленных памятников ранних кочевников в рассматриваемом регионе позволяет провести предварительное районирование, вычленение группы микрорайонов, привязанных к бассейнам степных рек левобережья Урала. В перспективе направление исследований будет ориентировано на сравнительный анализ между микрорайонами: Илекским, Темиро-Эмбенско-Сагизским, ОрьИргизским и Уило-Кобдинским. На территории обозначенных микрорайонов присутствуют свои элитарные группы памятников, являвшиеся, соответственно, консолидирующими центрами племенных группировок в рамках пастбищно-кочевой системы.

Аридность и континентальность климата, нарастающие с севера на юг и с запада на восток, являются важными характеристиками, определяющими уровень роста растительности, связанной с кормовой базой, численностью разводимого скота, и соответственно, с численностью проживавшего населения. Приспособление человека в сложных условиях привело к созданию максимально эффективной экономики, сообразно окружающей 
среде, и, в конечном итоге, выразилось в увеличении численности населения в середине I тыс. до н.э. Памятники ранних кочевников по территории левобережья Урала численно доминируют над памятниками других эпох. Занимая возвышенные территории - гребни водоразделов, вторые надпойменные террасы, платообразные возвышенности, археологические объекты ранних кочевников образуют комплексы памятников от одиночных и парных курганов, до могильников с сотнями насыпей [Ахатов, Бисембаев, 2015, с. 503-515].

При развитии кочевого скотоводства в его локальных и региональных вариантах важное значение приобретает гидросеть, ее густота, насыщенность и обеспечение потребностей кочевого хозяйства. Поверхностные воды региона состоят из водотоков (постоянных и временных), бессточных озер. Реки принадлежат к внутренним замкнутым бассейнам Каспийского и Аральского морей. Характер гидрографической сети, режим и сток рек региона существенно зависит от широтной зональности климата и ландшафтов. В связи с дефицитом влаги, особенно в пустынных районах, поверхностный сток мал, речная сеть разрежена, а реки маловодны. С ландшафтно-климатической зональностью связана неравномерность густоты речной сети. В степной зоне она равна $0,1-0,5$ км/км², в пустыне снижается до 2 м/км² и даже до 0 [Физическая..., 1998, с. 79]. Важным фактором, напрямую связанным с гидрографическими условиями и оказывающим самое непосредственное влияние на динамику скотоводческого хозяйства, демографические аспекты (концентрация или дисперсность в локализации кочевых группировок), является объем биомассы растительного покрова. Распределение растений и самой растительности подчинено общему закону горизонтальной и вертикальной зональности. По растительному покрову Приаральско-Мугалжарский регион содержит элементы четырех зон. По берегу Урала незначительно, но присутствует лесостепь. Далее, проходит зона настоящих степей, значительная средняя часть региона включается в зону пустынных степей или полупустынь, южная часть находится в зоне пустынь.

Илек - магистральный, левобережный приток Урала, несущий свои воды по меридиану, и таким образом максимально комфортен для кочевания с севера на юг вдоль его берегов. Он полноводен и сам имеет богатые притоки, способные обеспечить жизнедеятельность больших скотоводческих коллективов. Среднее течение проходит по ПриаральскоМугалжарскому региону и весьма насыщенно право- и левобережными притоками.

Илекский археологический микрорайон насыщен интересными и высокоинформативными памятниками раннего железного века. В начале XXI в. здесь были изучены могильники Бисоба, Шпаки II, Кураша I, Кайынбулак II. В данной публикации будут рассмотрены наиболее яркие и показательные погребальные комплексы этих могильников.

Могильник Бисоба, расположенный на полях АО «Родники», подвергался регулярной распашке, постепенно теряя свои первоначальные размеры. После длительных переговоров было достигнуто соглашение между руководством Акционерного общества и КГУ «Центр исследования, реставрации и охраны историкокультурного наследия», позволившее 
исследовать в полевом сезоне 2018 г. три кургана №№ 3, 8, 9. Могильник, зафиксирован в начале XX в. С.П. Банновым. Он расположен севернее пос. Родниковка (Мартукский p-н, Актюбинская обл.) и приурочен к правому берегу Илека, в его среднем течении. Памятник находится на обширном плато южнее начала КиялыБуртя и севернее Терис-Бутака. Объекты могильника раскапывались в 1977 и 1986 гг. [Китов, Мамедов, 2014, c. 14-15].

Курган № 8 диаметром 48 м и с сохранившейся, после многолетней распашки, высотой 2 м. Параметры объекта свидетельствуют о том, что его сооружение изначально было связано с высокой степенью трудозатрат, а также указывают на принадлежность погребенных к элитным группам населения. При исследовании насыпь была снята тремя траншеями, с оставлением стратиграфических профилей по линии 3-В. В насыпи кургана в западной его части выявлены кости лошади без элементов узды; в юго-восточной - кости животных: мелкого и крупного рогатого скота, а также интересный экземпляр акинака со следами вторичного использования. В северной части кургана кроме костей лошади обнаружены две пары двусоставных двукольчатых железных удил.

В центральной части кургана был сооружен «помост» из дерева и коры, диаметром около 17-18 м, со следами посыпки мелом. На помосте расчищено погребение № 1, содержащее останки трех человек, с южным сектором ориентировки. Сопровождающий предметный комплекс представлен тремя деформированными разных по размеру котлами с ручками, имевшими грибовидные выступы; акинаками; наконечниками стрел; зеркалом; развалами сосудов; массивным наконечником копья; железной портупейной обоймой, декорированной плакированным листком золотой фольги зигзагообразным орнаментом; золотым кольцом на мизинце левой руки второго погребенного (рис. 1). Второе погребение находилось под «помостом», юго-западнее центра. Погребение № 3 конструктивно отличается от предыдущего, так как имеет западную ориентировку; выполнено в виде глубокой и значительной по размерам катакомбы(?), с обрушившимся сводом, протянутой по линии 3-В, и перпендикулярным по линии C-Ю входом «дромосом» с входными ступенями. Сопровождающий инвентарь представлен круглым каменным жертвенником с ножками в виде голов волка, наконечниками стрел, крупным плоским бронзовым зеркалом, гадальными камешками, железными стержнями (рис. 2, 3).

Курган № 3 расположен несколько западнее самого крупного объекта могильника, диаметром 24 м и с сохранившейся высотой около 20 см. В насыпи зафиксированы кости лошади и предметы конской упряжи из железа и бронзы. Центр кургана изрезан норами грызунов, сильно потревоживших погребения. Погребения 1 и 3 имели южную ориентировку захороненных и весьма богатый сопровождающий инвентарь - каменный жертвенник на двух ножках, акинак с бабочковидным перекрестием и зооморфным навершием, зеркала, наконечники стрел и остатки сосудов (рис. 2, 1, 2). Из погребения 1 подняты пять экземпляров оригинальных зооморфных бронзовых подвесок размерами около $3,5 \times 2,5 \times 1,5$ см, представлявших собой соединение двух фигур животных, в двух плоскостях - горизонтальной и вертикальной. 
Бисембаев А.А., Хаванский А.И., Ахатов Г.А., Дуйсенгали М.Н., Мамедов А.М., Бидагулов Н.T., Уразова А.Б., Амелин В.А., Баиров Н.М. Работы последних лет...
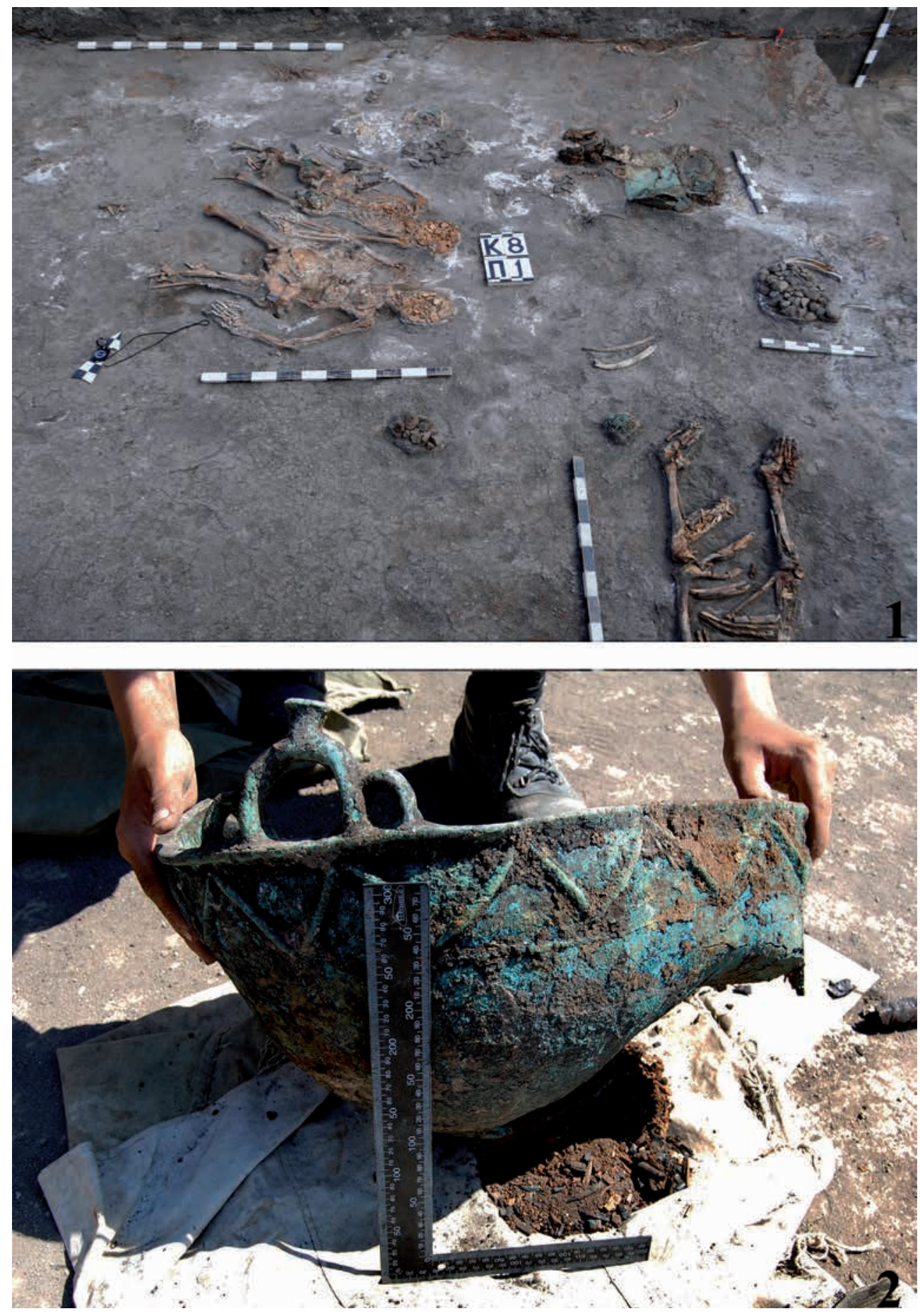

Рис. 1. Могильник Бисоба, к. № 8, n. 1. 1 - придонная часть погребения; 2 - бронзовый котел. Фото А.А. Бисембаева

Fig. 1. Burial site Bisoba, mound number 8, grave 1. 1 - the bottom part of the burial; 2 - bronze cauldron. Photo by Bisembayev A. 


\section{ҚАЗАҚСТАН АРХЕОЛОГИЯСЫ № 1 (3) 2019}
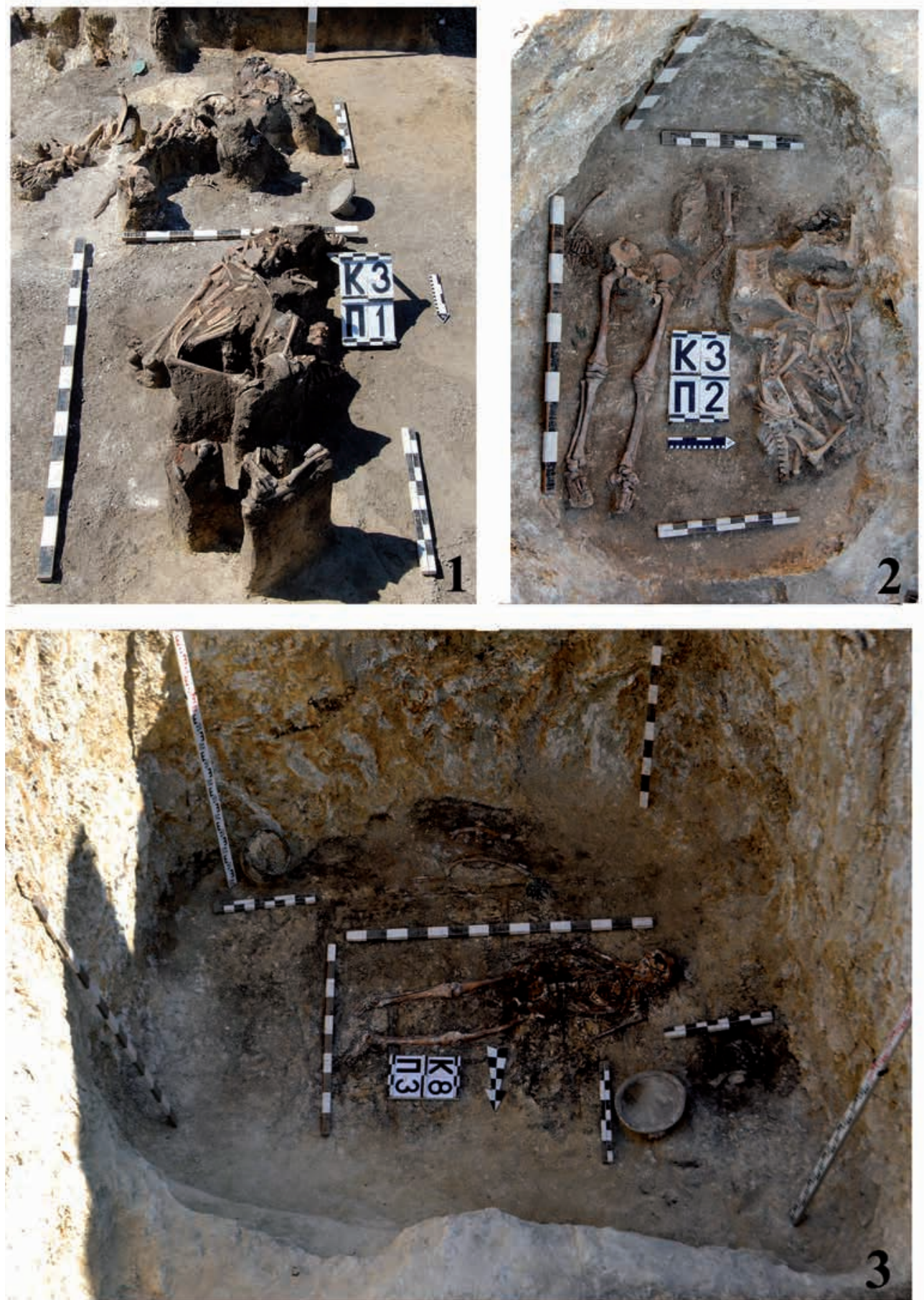

Рис. 2. Погребения из курганов №№ 3 и 8 могильника Бисоба. 1 - к. № 3, n. 1; 2 - к. № 3, n. 2; 3 - к. № 8, n. 3. Фото А.А. Бисембаева

Fig. 2. Burials from the mounds No. 3 and 8 of the Bisoba burial. 1 - mound number 3 , burial 1;2-mound number 3, burial 2; 3 - mound number 8, burial 3.

Photo by Bisembayev A. 
С одной стороны - это грифон с головой, повернутой назад и небольшим плоским хвостом. С другой стороны - это черепаха (скорпион, ящерица?). При этом хвост грифона служит ее головой, а голова грифона - согнутым в кольцо хвостом. Идентичные образы авторам раскопок не известны.

Курган № 9, расположенный в юго-восточной части могильника, погребальных ям не содержал. Вероятно, он представляет собой ритуальное сооружение, в пользу чего свидетельствует мощный, до 15 см толщиной, слой прокаленной почвы, а также зола и угольки, выявленные в различных частях этого сооружения. Кроме того, здесь зафиксированы вкрапления мела. По внешним параметрам объект обнаруживает сходство с курганом № 3, но он несколько выше (до $0,3 \mathrm{~m})$.

В целом, данные полученные в ходе исследования могильника Бисоба, - ориентировка погребенных (запад и юг); инвентарный комплекс, содержащий каменные жертвенники, акинаки, наконечники стрел, бронзовые котлы и предметы конской упряжи, зеркала и лепные сосуды, относящиеся к рубежу VI-V вв. до н.э., - пополняют источниковую базу по памятникам Илекского микрорайона.

Наиболее близким по локализации и по топографической ситуации к описанному выше памятнику (расположение на обширном плато с выходом к руслам пересохших и действующих родников и ручьев), является могильник Шпаки II. Он также в течение длительного времени подвергался распашке, что привело к потере первоначальных размеров и форм насыпей. Здесь исследованы два кургана.

Курган № 3 расположен в центральной части могильника, диаме- тром около 22 м и с сохранившейся высотой менее 1 м. В ходе раскопок объекта была отработана фиксация материала и предпринята попытка построения трехмерной модели. Для чего последовательно, после полного документирования, был вынесен весь грунт насыпи, включая и бровки. Фотофиксация велась вкруговую, с одних и тех же точек, после снятия слоев насыпи. С целью сохранения элементов подкурганных конструкций первоначально по периметру насыпи были заложены радиальные шурфы.

В результате полного выбора грунта был сохранен и полностью прослежен основной элемент подкурганной погребальной конструкции - земляной вал, в диаметре составлявший 14,5 м. Максимальная ширина вала была зафиксирована в северо-западной части и составила 2,3 м. Наиболее узкая ширина вала выявлена в южной части - 1,2 м. Поверхность вала представлена светложелтым суглинком с примесью песка (рис. 3,1 ). Основное, интересное по погребальному обряду и инвентарному набору, погребение № 2 располагалось в центральной части кургана. Общие размеры могильной ямы составили $3,8 \times 3,1$ м, глубина 1,5 м. Зафиксированы остатки деревяного перекрытия, оказавшегося продавленным внутрь на 1,12 м и представлявшего собой конус, направленный вершиной вниз. На дне погребения были зачищены хорошо сохранившиеся два скелета (рис. 3, 2). Оба костяка ориентированы в восточном направлении. В северной и восточной части погребения, у стен были обнаружены кости МРС и лошади. Между костяками животных зафиксированы два керамических лепных сосуда различной сохранности. Первый, сохра- 


\section{ҚАЗАҚСТАН АРХЕОЛОГИЯСЫ № 1 (3) 2019}
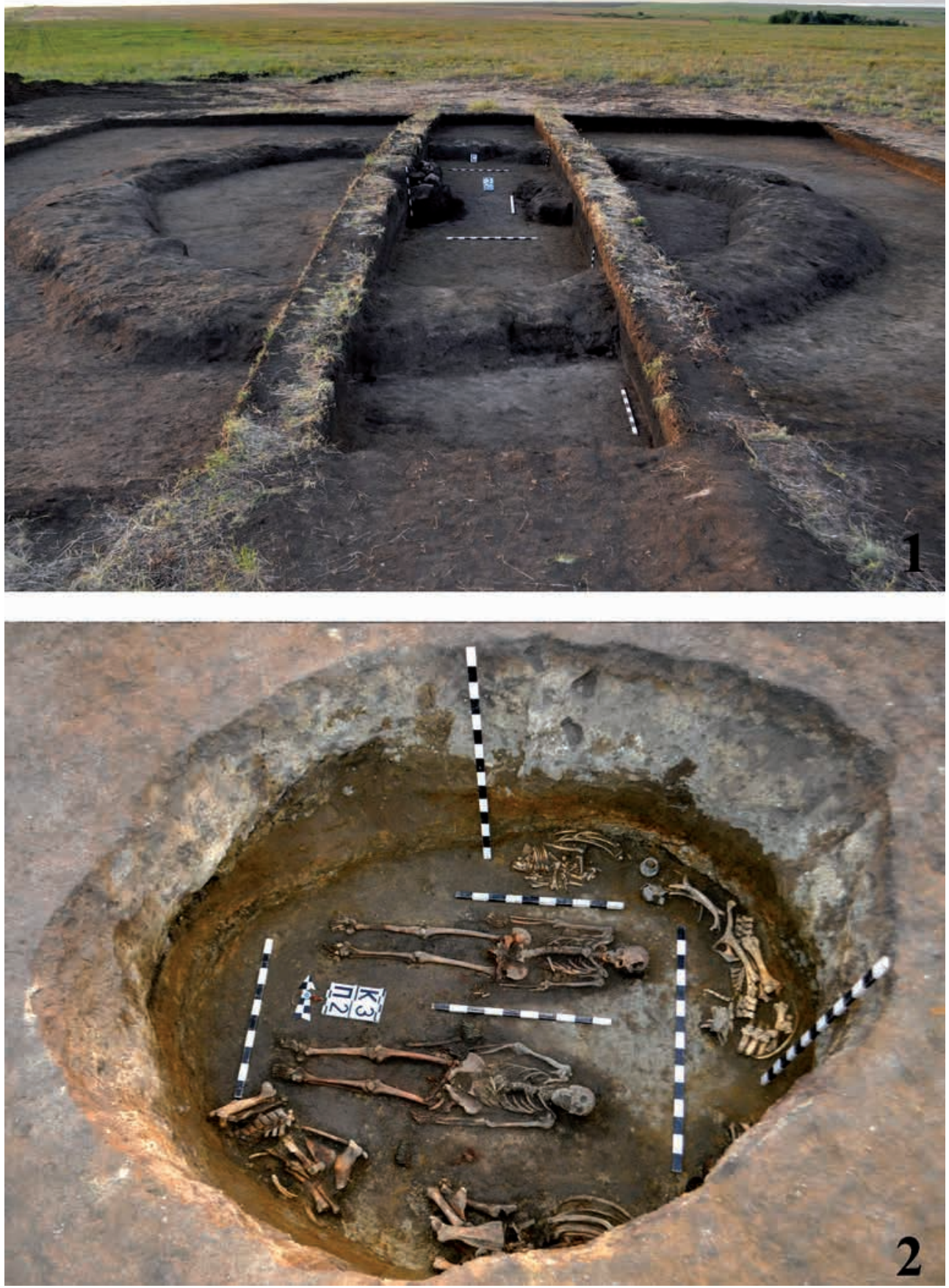

Рис. 3. Могильник Шпаки II, к. № 3. 1 - общий вид раскопа; 2 - погребение 2. Фото А.А. Бисембаева

Fig. 3. Burial ground Shpaki II, barrow number 3. 1 -a general view of the excavation; 2 - burial 2. Photo by Bisembayev A. 
нившийся, сосуд имел яйцевидное тулово и плоское дно. Высотой 10,7 см, диаметром: венчика 8 см, дна - 7,5 см. Второй был разрушен при завале могильной ямы.

Сосуды похожих очертаний и пропорций, несколько более крупных размеров, располагались между костяком № 2 и костями МРС (обнаруженных вдоль подножия ЮВ стенки). Инвентарь погребения представлен железными акинаками хорошей сохранности, на тазовых костях обоих костяков, имитирующими стандартное расположение в ножнах. Они имели определенное различие в размерах, но в остальном прослеживается сходство. Общая длина кинжала у костяка № 2 составила 28 см. Лезвие в длину составляет 17 см, ширина у перекрестия - 3,5 см. Перекрестие бабочковидное, навершие брусковидное. Длина рукояти $-8,5$ см, ширина 3,3 см. Кроме того, обнаружены костяная игла, железная ворворка, колчанный крюк, бронзовые наконечники стрел, амулет из кабаньего клыка. У ладони костяка № 2 был найден оргинальный костяной предмет, выполненный в зооморфном стиле. Вероятно, это рукоять нагайки, длиной 29,5 см, диаметр сечения 1,8 см. На концах предмета прослеживаются украшения скульптурами волка с оскаленной пастью. На одном из концов видны следы сильной потертости.

Погребение № 1 было врезано в основное погребение (№ 2) в центральной части кургана (в 50 см к западу от условного центра). На поверхности погребения прослеживалось надмогильное сооружение из камней прямоугольной формы со скругленными углами. Камни различных форм и величины были углублены в материк. Высота сооружения от уровня материка составила $65 \mathrm{~cm}$, длина 1,8 м, ширина 97 см. В процессе вскрытия погребения, на дне, был расчищен скелет взрослого человека, головой ориентированного на ЮЮЗ. Погребенный лежал на спине, руки вытянуты вдоль тела. Инвентарь скуден и представлен фрагментом железного изделия, разрушенным сосудом, фрагментом железного изделия и акинаком. Длина акинака составила 27 см. Перекрестие - бабочковидное. Форма навершия меча в виду плохой сохранности не устанавливается. Лезвие сужалось от рукояти к острию. Ширина лезвия у перекрестия -3 см, длина - 22 см. Ширина рукояти достигает -3 см, длина -5 см.

Курган № 4 (диаметр 20 м, высота 0,8 м). В ходе исследования насыпи в центральной траншее были выявлены остатки деревянной конструкции, сожженной еще в древности. Поверх конструкции находились элементы каменной выкладки, скорее всего, разброс камней образовался в результате распашки насыпи. Также в центральной траншее были обнаружены фрагменты керамических сосудов и пряслице, выполненное из керамики. В центральной части кургана были обнаружены кости МРС. Помимо костей животных, в насыпи фиксировались и кости человека (рис. 4, 1).

Из погребения № 1, обнаруженного в 3 м к северу от основного погребения кургана, подняты гадальные камни, выложенные в пирамидальную конструкцию, жертвенник на двух ножках между правым боком и рукой погребенной, бронзовое зеркало, бусы, каменное пряслице. Ориентировка погребенного человека западная. Могильная яма неглубокая - 83 см, размеры подпрямогульной по форме ямы 2,3×1,72 м (рис. 4, 2). 


\section{ҚАЗАҚСТАН АРХЕОЛОГИЯСЫ № 1 (3) 2019}
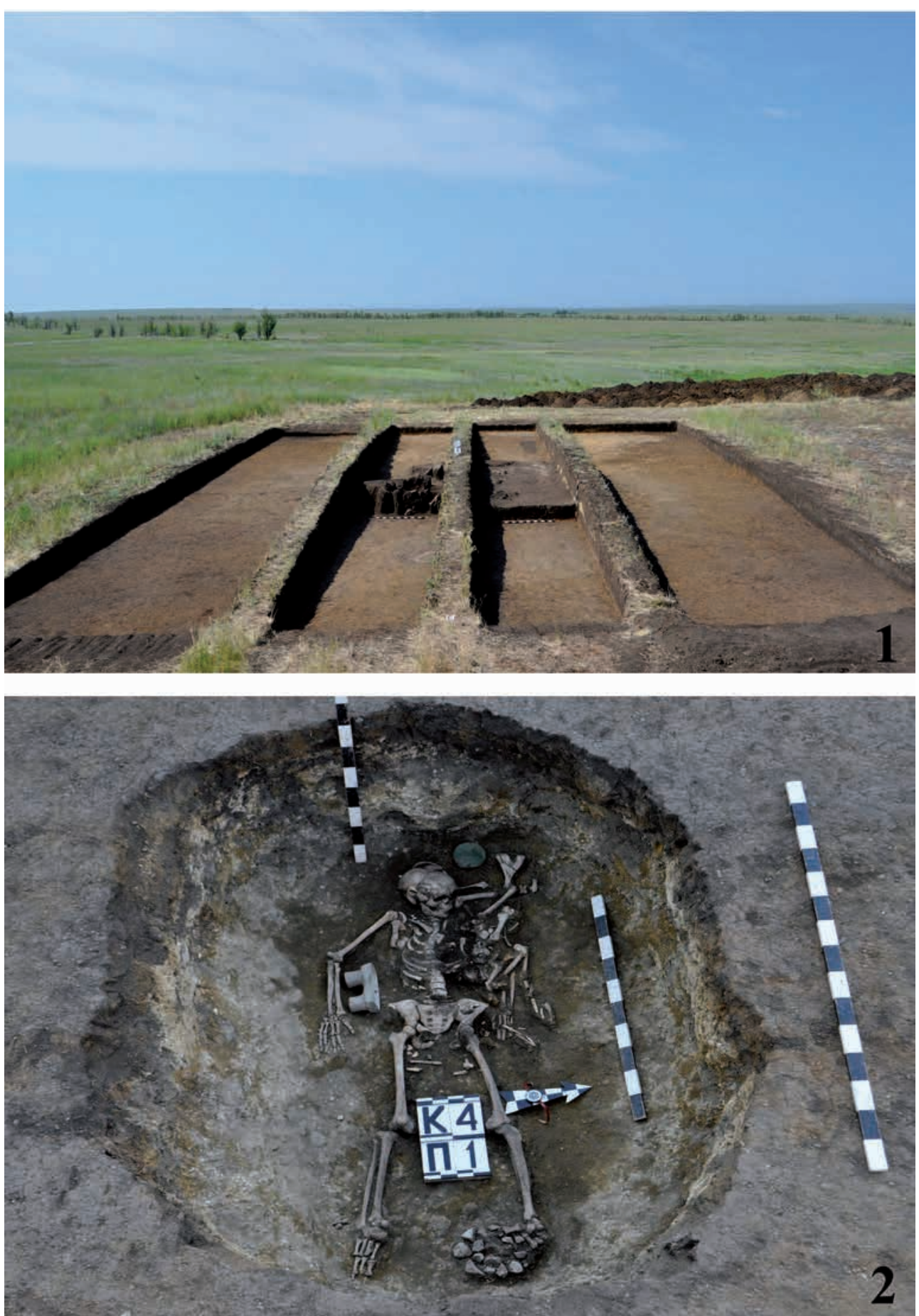

Рис. 4. Могильник Шпаки II, курган № 4. 1 - общий вид раскопа; 2 - погребение 1. Фото А.А. Бисембаева

Fig. 4. Burial ground Shpaki II, barrow no. 4. 1 -general view of the excavation; 2 - burial 1. Photo by Bisembayev A. 
Бисембаев А.А., Хаванский А.И., Ахатов Г.А., Дуйсенгали М.Н., Мамедов А.М., Бидагулов Н.T., Уразова А.Б., Амелин В.А., Баиров Н.М. Работы последних лет...
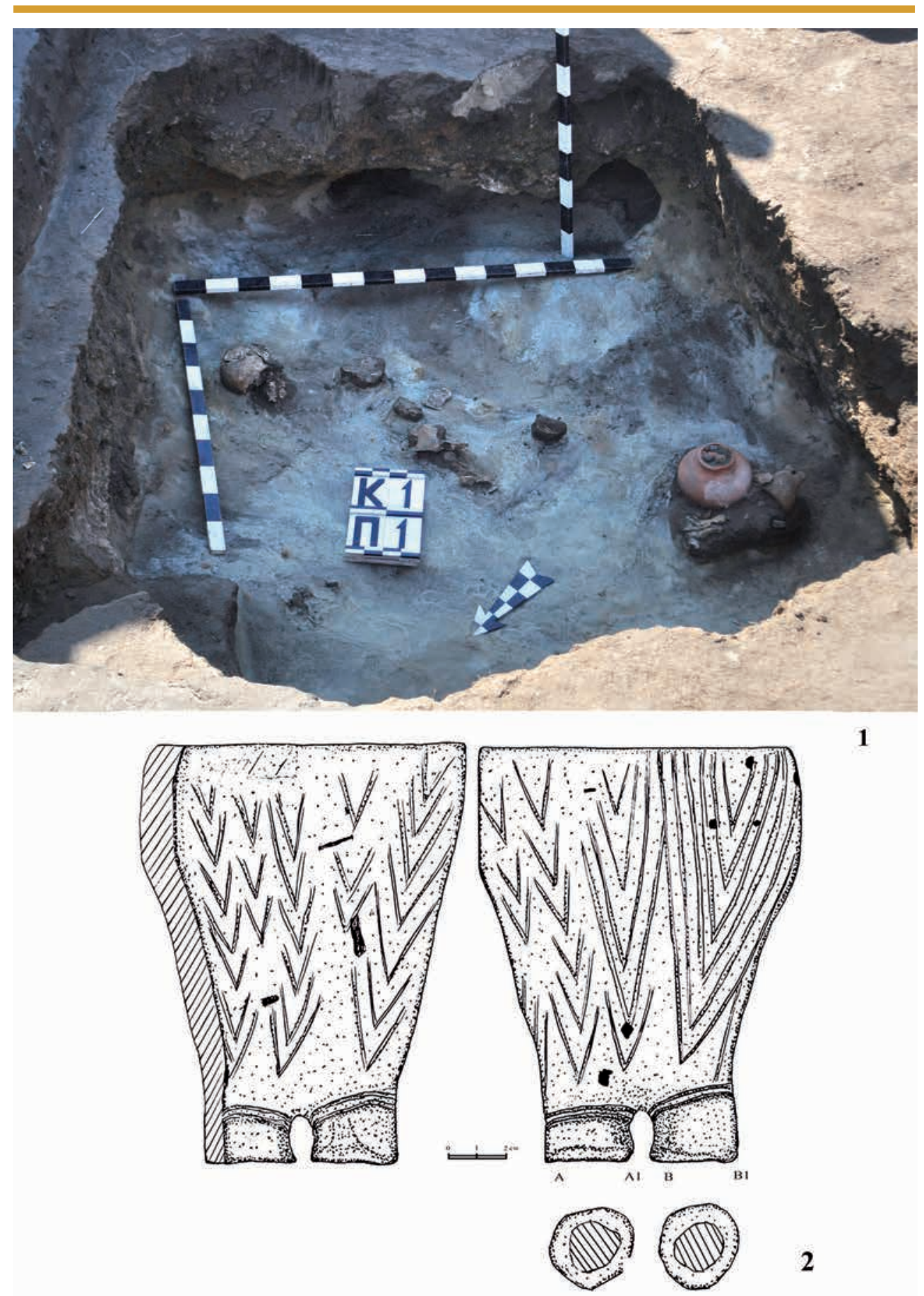

Рис. 5. Курган Кураша I, n. 1. 1 - придонная часть погребения; 2 - курильница. Фото А.А. Бисембаева

Fig. 5. Mound of Kurash I, burial 1. 1-bottom part of the burial; 2 -incense burner. Photo by Bisembayev A. 

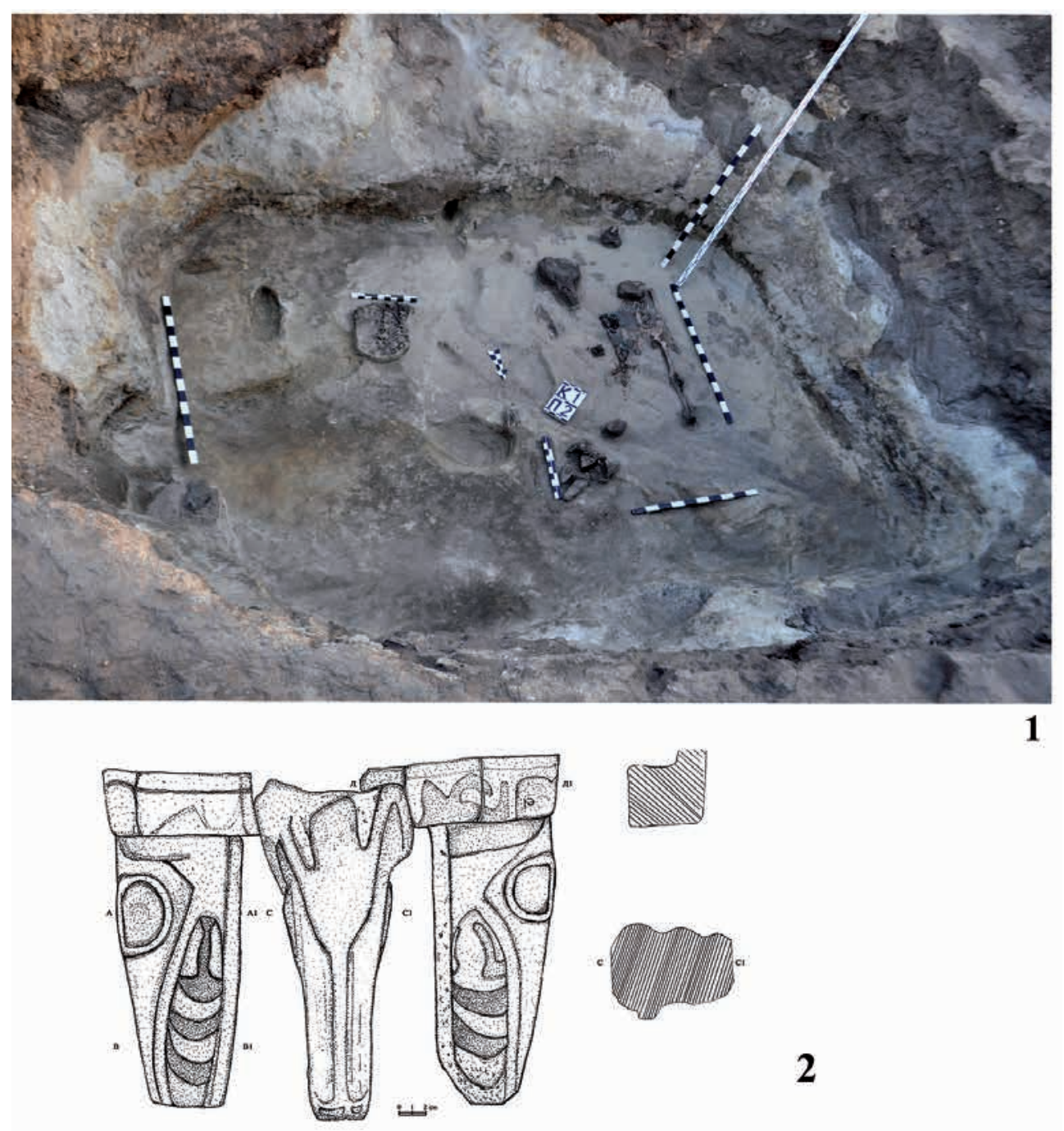

2

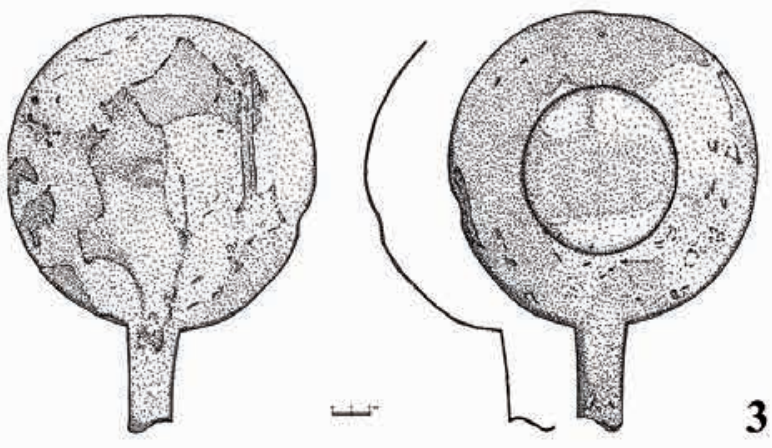

Рис. 6. Курган Курама I, n. 2. 1 - придонная часть погребения; 2 - каменный алтарь; 3 - бронзовое зеркало. Фото А.А. Бисембаева

Fig. 6. Mound Kurasha I, burial 2. 1 - the bottom part of the burial; 2 -stone altar; 3 - a bronze mirror. Photo by Bisembayev A. 
На дне погребения № 2, выявленого в 4 м к югу от условного центра кургана, был зачищен хорошо сохранившийся скелет мужчины, ориентированный головой на запад. Левая нога согнута в коленном суставе - погребенному придана атакующая поза. В плане могила имела прямоугольную форму со скругленными углами, размерами $3,7 \times 3$ м, глубина 1,95 м. В ходе спуска в погребение была обнаружена обожженная деревянная конструкция, на юго-западной окраине которой, на уровне материковой почвы, была зафиксирована часть обломанного жертвенника. Длина чаши составила 11 см, ширина - 13 см. Ножки цилиндрической формы длиной 3-3,9 см, диаметром 5 см. Из погребения происходят керамический сосуд, бронзовые наконечники стрел различных типов (65 штук), керамическая курильница, костяная ложечка, колчанный крюк.

Погребение № 3, расположенное ближе к центру, подверглось ограблению в древности - на уровень материка выброшены кости человека и животных. В дромосном погребении обнаружен яйцевидный по форме сосуд, с горловиной средней высоты, прямой, венчик слегка отогнут по краю. Размеры сосуда: высота 20,8 см, диаметры: венчика - 11 см, донца - 6 см. Наибольший диаметр тулова (в средней части) - 19,5 см.

Курган Кураша I расположен в 11 км восточнее пос. Родниковка, на водоразделе к северу от балки Кураша, относящейся к р. Жаздыбай, притоку р. Жаксы-Каргалы, правобережному притоку Илека.

Даже после многолетних пахотных работ размеры кургана на начало раскопок были внушительные - диаметр около 40 м и сохранившаяся высота 1,3 м. При снятии насыпи обнару- жены фрагменты деревянного столба - основы шатровой деревянной конструкции. Вокруг погребальной площадки был выложен глиняный кольцевой вал. Под курганной насыпью были обнаружены два погребения. Погребение № 1 находилось к северу от условного центра под глиняным валом (рис. 5). Погребение № 2, являвшееся основным, располагалось в центральной части погребальной площадки (рис. 6).

Могильная яма представляла собой дромосное захоронение глубиной 240 см. Яма также оказалось богатой на находки разнообразных предметов, в том числе и культовых. В юго-западной части дна погребения, на глубине 2,4 м, был обнаружен костяк № 1 плохой сохранности. У правой руки усопшего был расположен железный акинак. Также в яме были обнаружены золотые накладки, бронзовое зеркало, каменный алтарь, бронзовые наконечники стрел в количестве 183 штук. Оригинальными предметами, происходящими из данного памятника, являются железная обойма с золотой аппликацией и крупный каменный жертвенник на трех ножках. Обойма была обнаружена справа от костяка № 1. Рядом находились фрагменты железного ножа плохой сохранности, железные поясные пряжки, покрытые желтым металлом. Обойма представляля собой железное изделие подквадратной формы с длиной сторон 60×65 мм. Лицевая сторона изделия плакирована листовым золотом, художественно оформленным в зверином стиле.

В 2017 году в Илекском локальном микрорайоне исследовался могильник Кайынбулак II. Акцент в исследованиях был сделан на памятниках групп населения, обслуживающего илекскую кочевую элиту, со- 


\section{ҚАЗАҚСТАН АРХЕОЛОГИЯСЫ № 1 (3) 2019}
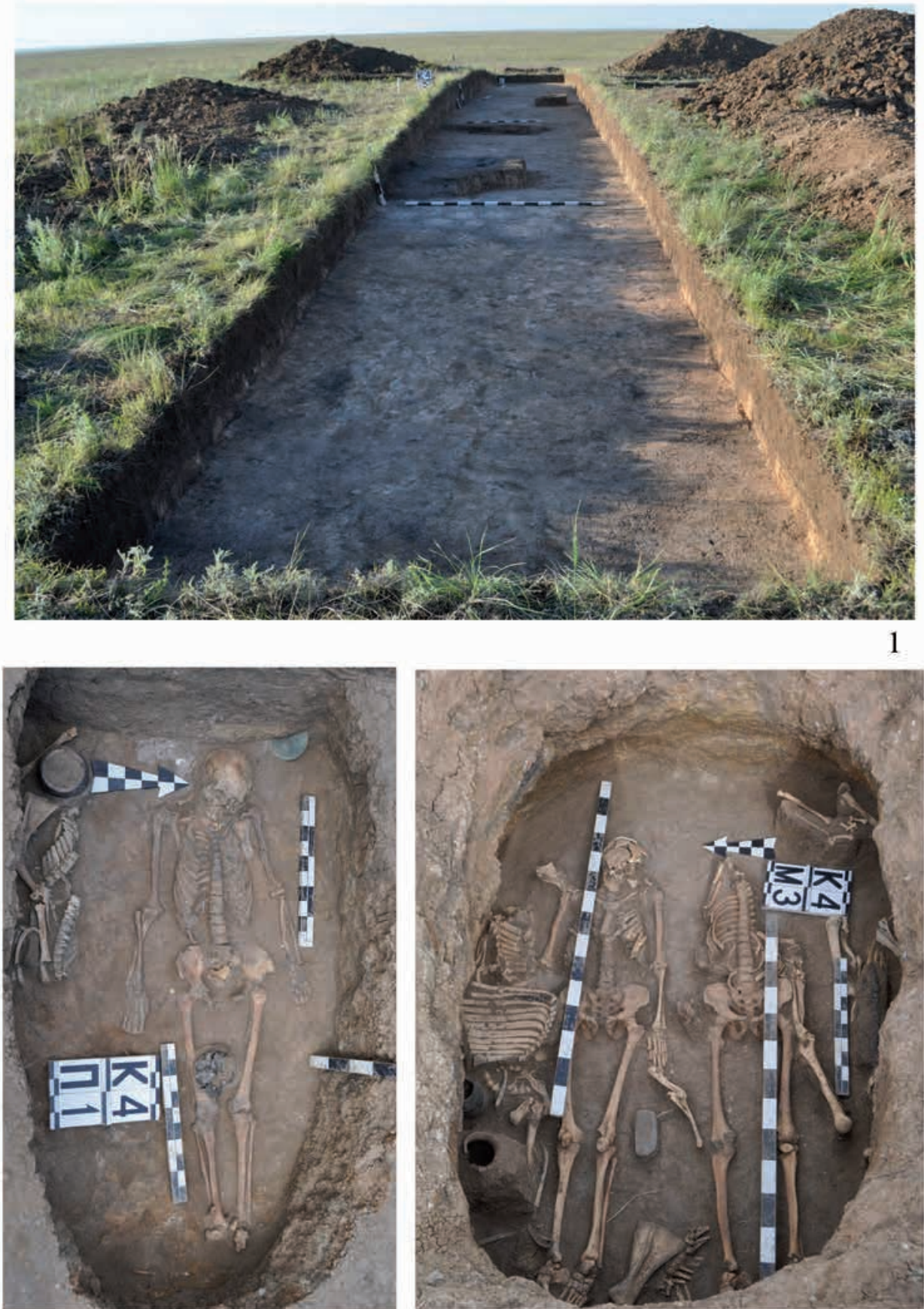

Рис. 7. Могильник Кайьннбулак I, к. № 4. 1 - иентральная траншея; 2 - погребение 1; 3 - погребение 3. Фото А.А. Бисембаева

Fig. 7. Kayynbulak I burial ground, barrow no. 4. 1 - central trench; 2 - burial 1; 3 - burial 3. Photo by Bisembayev A. 
средоточенных в восточной половине могильника. Курганы незначительных размеров, потерявшие внешние признаки на сегодняшний день, выявлялись путем сплошного снятия гумусного слоя с поля, на котором они располагались. В результате выноса значительного объема грунта были обнаружены почти все курганы, отраженные в планах 1980-х гг. Инвентарные комплексы в этих памятниках достаточно насыщены и своеобразны для своего круга (рис. 7).

O хроно-культурной принадлежности исследованных памятников предварительные выводы были сделаны ранее в ряде работ [Серик, Амелин, 2016, с. 182; Бисембаев и др. 2018]. Новые памятники Илекско- го локального микрорайона, периода VI-IV вв. до н.э., подчеркивают особую роль данной территории в географических рамках Западного Казахстана, выраженную как в насыщенности микрорайона памятниками, так и в их яркости и оригинальности, как в элементах погребального обряда, так и в комплексе сопровождающего инвентаря. В условиях благоприятной экологической ниши бассейна среднего течения Илека находилась кочевая элита середины - начала второй половины I тыс. до н.э. Следует подчеркнуть, что исследовались аварийные памятники, подвергшиеся антропогенному воздействию, не самые крупные в могильных полях, расположенные по периферии.

\section{ЛИТЕРАТУРА}

1. Акишев К.А. К проблеме происхождения номадизма в аридной зоне древнего Казахстана // Поиски и раскопки в Казахстане. Алма-Ата: «Наука», 1972. С. 31-46.

2. Ахатов Г.А., Бисембаев А.А. Характеристика природно-географических условий Западного Казахстана как экониши кочевого населения раннего железного века и средневековья // Казахское ханство в потоке истории: сб. научн. ст., посвящ. 550-летию образования Казахского ханства. Алматы: Институт археологии им. А.Х. Маргулана, 2015. C. 503-513.

3. Бисембаев А.А. Заметки к аспектам региональной истории: общее и особенное Западно-Казахстанского региона // Вестник ЕНУ им. Л.Н. Гумилева. 2009. № 3 (70). C. 217-222.

4. Бисембаев А.А., Ахатов Г.А., Мамедов А.М., Дуйсенгали М.Н., Амелин В.А., Бидагулов Н.T., Жанузак Р.Ж. Исследование памятников кочевников ПриуральскоМугалжарского региона в 2015-2017 гг. // Маргулановские чтения - 2018. Духовная модернизация и археологическое наследие: сб. матер. Междунар. научн.-практ. конф. Алматы-Актобе, 2018. С. 28-42.

5. Китов Е.П., Мамедов А.М. Кочевое население Западного Казахстана в раннем железном веке. Астана: издат. гр. филиала Института археологии им. А.Х. Маргулана, 2014. $352 \mathrm{c}$.

6. Серик Г.С., Амелин В.А. К вопросу об изображениях оленей в искусстве ранних кочевников // Археология, этнология и музеология в системе современного высшего образования: матер. междунар. научн.-методич. конф. «VIII Оразбаевские чтения». Алматы: «Қазақ университеті», 2016. С. 182-184.

7. Смирнов К.Ф. Сарматы на Илеке. М.: Наука, 1975. 176 с.

8. Физическая география Республики Казахстан / Под ред. Джаналиевой Г.М. Алматы: «Қазақ университеті», 1998. 265 с.

\section{Сведения об авторах:}

Бисембаев Арман Ауганович - кандидат исторических наук, старший научный сотрудник, Институт археологии им. А.Х. Маргулана, представитель Института археологии им. А.Х. Маргулана в Западном Казахстане (г. Актобе, Казахстан); abissembaev@mail.ru 
Хаванский Алексей Иванович - кандидат исторических наук, старший научный сотрудник, Институт археологии им. А.Х. Маргулана КН МОН РК (г. Алматы, Казахстан); Arkaim01@yandex.ru

Ахатов Газиз Аманжолович - старший научный сотрудник, Институт археологии им. А.Х. Маргулана (г. Алматы, Казахстан); g akhatov@mail.ru

Дуйсенгали Мейрам Нурланович - и.о. директора, Актюбинский областной историко-краеведческий музей (г. Актобе, Казахстан); duisenglimeiram@mail.ru

Мамедов Аслан Маликович - директор, Центр исследования, реставрации и охраны историко-культурного наследия (г. Актобе, Казахстан); mamedovaslan@mail.ru

Бидагулов Нурбол. Т. - старший научный сотрудник, отдел «Археология и этнография», Актюбинский областной историко-краеведческий музей (Актобе, Казахстан)

Уразова Асель Бейбутовна - старший научный сотрудник, отдел «Археология и этнография», Актюбинский областной историко-краеведческий музей (г. Актобе, Казахстан); urazova-asel@mail.ru

Баиров Нурсултан Майлибаевич - научный сотрудник, отдел «Археология и этнография», Актюбинский областной историко-краеведческий музей (г. Актобе, Казахстан); nmbairov91@mail.ru

Амелин Виктор Алексеевич - научный сотрудник, отдел «Археология и этнография», Актюбинский областной историко-краеведческий музей (г. Актобе, Казахстан); vityara2706@mail.ru

\section{ІЛЕ МИКРОАЙМАҚЫНЫН ЕНШІЛІК НОМАДАЛАРЫНЫН ЖЫЛҒЫ ЖЫЛДАРЫ} (алдын ала нәтижелер)

\section{А.А. Бисембаев, А.И. Хаванский, Ғ.А. Ахатов, М.Н. Дүйсеңғали, А.М. Мамедов, Н.Т. Бидагулов, А.Б. Уразова, В.А. Амелин, Н.М. Баиров}

Мақалада Арал маңы-Мұғалжар аймағының Елек жергілікті ықшам ауданындағы ерте көшпелілер ескерткіштерінің соңғы жылдардағы зерттеу нәтижелері көрсетілген. 2015 жылдан бастап Ақтөбе облысының Мәртөк ауданы Родниковка ауылы маңында ерте көшпелілер ескерткіштерін жоспарлы зерттеу жүргізіліп келеді. Ескерткіштер тобы Елек өз. бассейініне тиісті және соған сәйкес ықшам ауданға жатқызылған. Соңғы жылдардағы Бисоба, Шпаки, Кураша және Қайынбұлақ бейіттеріндегі зерттеулер, сонымен қатар 60-80-ші жж. алынған материалдар б.з.д. І мың ж. Елек ықшам ауданындағы халықтың қоныстануы мен көшпелі топтардың элиталық сипаттары туралы айтуға мүмкіндік береді. Нысандардың айтарлықтай үлкендігі, табылған қола қазандар, ат әбзелдері, құрбандық тастары, қару-жарақтары және т.б. аймақтағы басым болған топтардың жарқын белгілері болып табылады.

Түйін сөздер: археология, Елек, Бисоба, Шпаки, Кураша, ерте көшпелілер, сарматтар, жерлеу ғұрпы

\section{WORKS OF THE RECENT YEARS ON MONUMENTS OF EARLY NOMADS OF THE ILEK MICROREGION (preliminary results)}

\section{A.A. Bisembayev, A.I. Khavansky, G.A. Akhatov, M.N. Duisengali, A.M. Mamedov, N.T. Bidagulov, A.B. Urazova, V.A. Amelin, N.M. Bairov}

This article is devoted to results of studies of the last years of the monuments of the early nomads of the Ilek local microdistrict of the Aral-Mugaljar region. Beginning in 2015 , systematic studies of the monuments of early nomads in the vicinity of Rodnikovka village of Martuk district of the Aktobe region are conducted. This group of monuments is belong to the Ilek river basin and is allocated to the corresponding microdistrict. Studies of the recent years of burial mounds in the burial grounds of Bisoba, Shpaki, Kurasha and Kaiynbulak, as well as materials obtained in the 1960-1980s, allow us to speak about the significant concentration of the population and the elite character of the nomadic groups that lived in the middle of I millennium BC in the Ilek local microdistrict. Significant sizes 
of objects like found bronze boilers, cast items of horse harness, stone altars, armaments and much more are bright signs of the dominant group in the region.

funeral rite

Keywords: archaeology, Ilek, Bisoba, Shpaki, Kurasha, early nomads, Sarmatians,

\section{REFERENCES}

1. Akishev, K. A. 1972. In Akishev, K. A. (ed.) Poiski i raskopki v Kazakhstane (Searches and excavations in Kazakhstan). Alma-Ata: «Nauka» Publ., 31-46 (in Russian).

2. Akhatov, G. A., Bisembayev, A. A. 2015. In Baitanayev, B. A. (ed.) Kazakhskoye khanstvo v potoke istorii (Kazakh Khanate in the flow of history). Almaty: A.Kh. Margulan Institute of Archaeology, 503-513 (in Russian).

3. Bisembayev, A. A. 2009. In Vestnik YENU im. L.N. Gumileva (Bulletin of the Eurasian National University named L.N. Gumilyov), 3, 217-222 (in Russian).

4. Bisembayev, A. A., Akhatov, G. A., Mamedov, A. M., Duysengali, M. N., Amelin, V. A., Bidagulov, N. T., Januzak, R. J. In Margulan okulary-2018 (Margulan readings-2018). Almaty-Aktobe, 28-42 (in Russian).

5. Kitov, Ye. P., Mamedov, A. M. 2014. Kochevoye naseleniye Zapadnogo Kazakhstana $v$ rannem zheleznom veke (The nomadic population of Western Kazakhstan in the early Iron Age). Astana (in Russian).

6. Serik, G. S., Amelin, V. A. 2016. In VIII Orazbayevskiye chteniya (VIII-th Orazbayev readings) Almaty: "Qazaq University" Publ., 182-184 (in Russian).

7. Smirnov, K. F. 1975. Sarmaty na Ileke (Sarmaty on Ilek). Moscow: «Nauka» Publ. (in Russian).

8. Fizicheskaya geografiya Respubliki Kazahstan (Physical Geography of the Republic of Kazakhstan). 1998. Janalieva, G. M. (ed.) Almaty: "Qazaq University” Publ. (in Russian).

\section{About the Authors:}

Bisembayev Arman A. Candidate of Historical Sciences, Senior Researcher, A.Kh. Margulan Archeology Institute, Aktobe, Kazakhstan; representative of the A.Kh. Margulan Archeology Institute in Western Kazakhstan; abissembaev@mail.ru

Khavansky Alexey I. Candidate of Historical Sciences, Senior Researcher, A.Kh. Margulan Archeology Institute, Almaty, Kazakhstan; Arkaim01@yandex.ru

Akhatov Gaziz A. Senior Researcher, A.Kh. Margulan Archeology Institute; g_akhatov@mail.ru

Duisengali Meiram N. Acting director, Aktobe regional museum of local lore, Aktobe, Kazakhstan; duisenglimeiram@mail.ru

Mamedov Aslan M. Director, Center for Research, Restoration and Protection of Historical and Cultural Heritage, Aktobe Kazakhstan.mamedovaslan@mail.ru

Bidagulov Nurbol T. Senior researcher, Department of Archeology and Ethnography, Aktobe Regional Museum of Local History, Aktobe, Kazakhstan

Urazova Asel B. Senior researcher, Department of Archeology and Ethnography, Aktobe Regional Museum of Local History, Aktobe, Kazakhstan; urazova-asel@mail.ru

Bairov Nursultan M. Research associate, department "Archaeology andEthnography", Aktobe regional museum of local lore, Aktobe, Kazakhstan; nmbairov91@mail.ru

Amelin Viktor A. Research associate, department "Archaeology and Ethnography", Aktobe regional museum of local lore, Aktobe, Kazakhstan. vityara2706@mail.ru

\footnotetext{
Мүдделер қақтығысы туралы ақпаратты ашу. Авторлар мүдделер қақтығысының жоқтығын мәлімдейді. / Раскрытие информации о конфликте интересов. Авторы заявляют об отсутствии конфликта интересов. / Disclosure of conflict of interest information. The authors claims no conflict of interest.

Мақала туралы ақпарат / Информация о статье / Information about the article. Редакцияға түсті / Поступила в редакцию / Entered the editorial office: 21.09.2018. Рецензенттер мақұлдаған / Одобрено рецензентами / Approved by reviewers: 28.09.2018 Жариялауға қабылданды / Принята к публикации / Accepted for publication: 05.10.2018.
} 